\title{
The First Case of Glyphosate Resistance in Johnsongrass (Sorghum halepense (L.) Pers.) in Europe
}

\author{
Jose G. Vazquez-Garcia ${ }^{1}$, Candelario Palma-Bautista ${ }^{1}\left({ }^{\circledR}\right.$, Antonia Maria Rojano-Delgado $^{1}$, \\ Rafael De Prado ${ }^{1}$ (D) and Julio Menendez ${ }^{2, *(D)}$ \\ 1 Agricultural Chemistry and Soil Sciences, University of Córdoba, 14014 Cordoba, Spain; \\ z82vagaj@uco.es (J.G.V.-G.); z82pabac@uco.es (C.P.-B.); arakidonis@hotmail.com (A.M.R.-D.); \\ qe1pramr@uco.es (R.D.P.) \\ 2 Departamento de Ciencias Agroforestales, Escuela Tecnica Superior de Ingenieria, Campus de La Rabida, \\ Universidad de Huelva, Palos de la Frontera, 21819 Huelva, Spain \\ * Correspondence: jmenend@uhu.es
}

Received: 29 January 2020; Accepted: 26 February 2020; Published: 3 March 2020

\begin{abstract}
Six Johnsongrass populations suspected of being glyphosate resistant were collected from railways and freeways near Cordoba (SW Spain), where glyphosate is the main weed control tool. The 50\% reduction in shoot fresh weight $\left(\mathrm{GR}_{50}\right)$ values obtained for these six populations ranged from 550.4 to $1169 \mathrm{~g}$ ae $\mathrm{ha}^{-1}$, which were 4.2 to 9 times greater than the value obtained for the susceptible population. Glyphosate was equally metabolized to the same extent in both resistant and susceptible populations, with no significant differences in either 5-enolpyruvylshikimate-3-phosphate synthase (EPSPS) inhibition or basal activity. No amino acid substitutions were observed in any of the resistant populations. Slight but significant differences in glyphosate penetration were observed among some but not all of the resistant populations and for the times of incubation assayed, although these differences were not considered further. The proposed primary mechanism of resistance in these six glyphosate-resistant Johnsongrass populations is reduced herbicide translocation, because the amount of glyphosate that translocated from treated leaves to shoots and roots in the susceptible population was double that observed in the resistant populations. As glyphosate multiple resistance due to more than one mechanism is not uncommon, this is the first time that glyphosate-resistant Johnsongrass populations have been fully described for all known mechanisms.
\end{abstract}

Keywords: translocation; metabolism; penetration; EPSPS; non-target site resistance; resistant weeds

\section{Introduction}

Johnsongrass is a $\mathrm{C} 4$ perennial and rhizomatous grass weed native to the Mediterranean region with a current range area between $55^{\circ} \mathrm{N}$ and $45^{\circ} \mathrm{S}$, which reproduces by seeds and rhizomes [1]. The vegetative propagation, high fecundity, seed dormancy, and residual seedbank life of Johnsongrass contribute to its weediness (reviewed in [2]), and make it one of the major weeds throughout the world [1], although its preeminence has been drastically downgraded with the use of the systemic herbicide glyphosate as the main weed-control tool for glyphosate-resistant crops [3].

Glyphosate is a broad-spectrum herbicide that exclusively acts via foliar uptake. The target site in plants is the inhibition of the enzyme 5-enolpyruvylshikimate-3-phosphate synthase (EPSPS) (EC 2.5.1.19), which catalyzes the conversion of shikimate-3-phosphate and phosphoenolpyruvate into 5-enolpyruvylshikimate-3-phosphate and inorganic phosphate in the shikimic acid pathway [4]. Inhibiting this enzyme prevents the biosynthesis of the aromatic amino acids phenylalanine, tyrosine, and tryptophan. Glyphosate has, for decades, been the leading and most widely used herbicide in agriculture [5]. The widespread adoption of glyphosate-resistant (GR) crop technology has been 
claimed to be one of the causes of its increasing use [6], although glyphosate has been extensively used in perennial crops and industrial areas as well. These industrial areas include path borders, railway lines, and recreation areas, where glyphosate has been used worldwide to control weeds [7]. Regardless of the cropping system, persistent reliance on glyphosate treatments as the exclusive weed management system has usually led to the evolution of glyphosate resistance in weeds [2], typically after 10 years of repeated applications [8]. Resistance to glyphosate has been classically ascribed to (a) reduced translocation of the herbicide, probably due to sequestration in the vacuole $[9,10]$, (b) mutations in DNA coding sequences leading to an altered resistant form of EPSPS [11-13], (c) overexpression of EPSPS through gene amplification [14], and (d) metabolization of glyphosate into non-toxic compounds [15-17]. Other less frequent, but described, resistance factors are (a) reduced foliar retention of the herbicide [18] and (b) reduced absorption of the herbicide $[19,20]$. These mechanisms are present in the 317 glyphosate-resistant biotypes belonging to forty-nine weed species and subspecies already described. These species include 39 glyphosate-resistant cases in non-crop areas [21]. In addition, five Johnsongrass cases have been reported in Argentina and the USA, all of which are associated with GR crops [21]. Of those five cases, only two American cases have been partially described [20,22]. Therefore, the Argentinian biotypes showed reduced glyphosate translocation and leaf uptake, while the Arkansas biotype only showed limited translocation. However, the Arkansas plants were not EPSPS sequenced, and these two published cases were not tested for glyphosate metabolism and EPSPS overexpression. This is important since glyphosate multiple resistance due to more than one mechanism is not uncommon [15,23,24].

The goal of the present study was to fully describe the resistance to the non-selective herbicide glyphosate in several Johnsongrass weed populations currently infesting different rail and roadways in southern Spain.

\section{Results and Discussion}

\subsection{Whole-Plant Dose-Response Assays}

The herbicide rates causing both a $50 \%$ mortality $\left(\mathrm{LD}_{50}\right)$ and $50 \%$ reduction in shoot fresh weight $\left(G_{50}\right)$ compared to non-treated controls were calculated. Therefore, the obtained $G_{50}$ and $L_{50}$ values allow comparisons of the results to those of other resistant Johnsongrass populations, such as the Argentinian glyphosate-resistant Johnsongrass [2] and the glyphosate-resistant Johnsongrass from Arkansas [22]. While the susceptible (S) population showed similar [22] or slightly greater [2] dose-response values than those reported in previously described $S$ populations, all the remaining six glyphosate-resistant populations (GR1 to GR6) tested were significantly resistant to glyphosate relative to the susceptible population in terms of both the effective dose growth reduction and mortality (Table 1). Both GR2 and GR5 were the most resistant populations, exhibiting resistance index (RI) values ranging from $10.96\left(\mathrm{GR} 2, \mathrm{LD}_{50}\right)$ to $8.18\left(\mathrm{GR} 5, \mathrm{GR}_{50}\right)$. Although they showed a lower degree of resistance than these two populations, GR1, GR3, GR4, and GR6 also displayed a significant level of resistance compared to $S$ plants, with RI values ranging from $7.94\left(\mathrm{GR} 4, \mathrm{LD}_{50}\right)$ to $4.23\left(\mathrm{GR} 1, \mathrm{GR}_{50}\right)$. Under these conditions, we could split the six populations into two groups: the first one included the GR2 and GR5 populations, which were $>10$-fold $\left(\mathrm{LD}_{50}\right)$ and $>8$-fold $\left(\mathrm{GR}_{50}\right)$, respectively, more resistant compared to the $S$ population. The second group included the rest of the populations, with $\mathrm{GR}_{50}$ and $\mathrm{LD}_{50}$ values lower than the thresholds set but still significantly different from the $\mathrm{S}$ values (Table 1 ). 
Table 1. Parameters of the log-logistic equations used to calculate the glyphosate rates required for $50 \%$ reductions in fresh weight $\left(\mathrm{GR}_{50}\right)$ and percent survival $\left(\mathrm{LD}_{50}\right)$ expressed as the percentage of the mean untreated control of the Johnsongrass populations.

\begin{tabular}{|c|c|c|c|c|c|c|c|c|c|c|}
\hline \multicolumn{6}{|c|}{ Survival (\%) } & \multicolumn{5}{|c|}{ Fresh Weight Reduction (\%) } \\
\hline Population & d & b & $\begin{array}{c}\mathrm{LD}_{50} \\
(\mathrm{~g} \text { ae ha-1 })^{a}\end{array}$ & $\mathbf{R I}^{\mathbf{b}}$ & $p$ & d & $\mathbf{b}$ & $\begin{array}{c}\mathrm{GR}_{50} \\
\left(\mathrm{~g} \mathrm{ae} \mathrm{ha}^{-1}\right)^{\mathrm{a}}\end{array}$ & $\mathbf{R I}^{\mathbf{b}}$ & $p$ \\
\hline GR1 & 97.31 & 3.18 & $1588.95 \pm 101.12$ & 7.69 & $<0.0001$ & 102.09 & 1.12 & $550.36 \pm 43.85$ & 4.23 & $<0.0001$ \\
\hline GR2 & 99.83 & 3.19 & $2265.54 \pm 56.63$ & 10.96 & $<0.0001$ & 102.53 & 1.53 & $1169.25 \pm 57.49$ & 8.99 & $<0.0001$ \\
\hline GR3 & 100.91 & 2.64 & $1410.91 \pm 68.25$ & 6.83 & $<0.0001$ & 101.15 & 1.48 & $959.02 \pm 60.35$ & 7.37 & $<0.0001$ \\
\hline GR4 & 100.10 & 2.09 & $1640.36 \pm 40.13$ & 7.94 & $<0.0001$ & 100.88 & 1.33 & $933.46 \pm 24.17$ & 7.17 & $<0.0001$ \\
\hline GR5 & 100.73 & 2.49 & $2121.83 \pm 120.06$ & 10.27 & $<0.0001$ & 101.81 & 1.59 & $1064.00 \pm 113.53$ & 8.18 & $<0.0001$ \\
\hline GR6 & 99.97 & 2.41 & $1448.68 \pm 62.04$ & 7.01 & $<0.0001$ & 100.07 & 1.11 & $751.30 \pm 59.75$ & 5.77 & $<0.0001$ \\
\hline GS & 100.07 & 4.45 & $206.55 \pm 2.85$ & - & & 102.73 & 1.53 & $130.02 \pm 13.59$ & - & \\
\hline
\end{tabular}

${ }^{a}$ Mean values $(n=10) \pm$ S.E. $L_{50}$ : glyphosate rate needed to increase mortality by $50 \%, \mathrm{GR}_{50}$ : glyphosate rate needed to reduce fresh weight by $50 \%,{ }^{b} \mathrm{RI}$ (Resistance Index): $\mathrm{GR}_{50}$ or $\mathrm{LD}_{50}(\mathrm{R}) / \mathrm{GR}_{50}$ or $\mathrm{LD}_{50}(\mathrm{~S})$.

The levels of resistance of both groups were similar to those of other Johnsongrass populations that have been described as highly resistant to glyphosate, such as the Arkansas [22] and Argentinian [2] populations. These populations are described as having an altered glyphosate translocation pattern [20,22], with this altered glyphosate translocation being responsible for the higher resistance. In addition, one of the Argentinian Johnsongrass populations showed reduced glyphosate leaf uptake [20].

\subsection{EPSPS Basal Activity and Inhibition}

Glyphosate target-site resistance (TSR) mechanisms have been associated with changes in EPSPS activity. These changes refer to both overexpression of the EPSPS gene associated with increased EPSPS gene amplification, EPSPS transcript levels, EPSPS protein expression, and/or genomic copy number, which increase its activity [14], or a mutation in the amino acidic sequence, which reduces its affinity for glyphosate binding [25]. In our case, there were no significant differences in terms of the EPSPS basal activity between the resistant and susceptible populations, with values ranging from 0.10 to $0.11 \mu \mathrm{mol}$ phosphate $\mu \mathrm{g}$ total soluble protein (TSP) ${ }^{-1}$ (Figure 1). No additional data about Sorghum halepense EPSPS activity is available for comparison, but our values were similar to those observed in other glyphosate-susceptible EPSPS enzymes, such as those isolated from several Conyza species [26]. Therefore, even in a polyploidy species such as Johnsongrass, with multiple genes encoding the EPSPS protein, the overexpression of the EPSPS gene leading to multiple functional copies of the EPSPS protein does not seem to be the mechanism of resistance, as EPSPS basal activity remains the same no matter the biotype tested. In addition, there were no significant differences in the $50 \%$ inhibition of EPSPS activity $\left(\mathrm{I}_{50}\right)$ values among all the populations tested, with estimated values ranging from 2.6 (GR6) to 3.4 (GR1) $\mu \mathrm{M}$ (Figure 1), which were even lower than those observed in other weed populations with glyphosate-susceptible EPSPS enzymes [26,27]. Therefore, a change of the sensitivity to glyphosate of the EPSPS enzyme is not the mechanism of resistance in the resistant populations.

\subsection{EPSPS Gene Sequencing}

TSR in glyphosate-resistant weed biotypes has been associated with amino acid substitutions at both the Thr102 and Pro106 positions of the EPSPS protein [28-30]. The partial sequence of the EPSPS2 gene revealed a similar sequence to those observed in glyphosate-resistant Argentinian populations [20], with no amino acid substitution at either the Pro106 or Thr102 positions in the glyphosate-resistant and -susceptible populations of Johnsongrass (Figure S1). These results, in conjunction with the patterns of EPSPS enzyme inhibition and basal activity, discard TSR mechanisms as the source of glyphosate resistance in resistant Johnsongrass populations. 


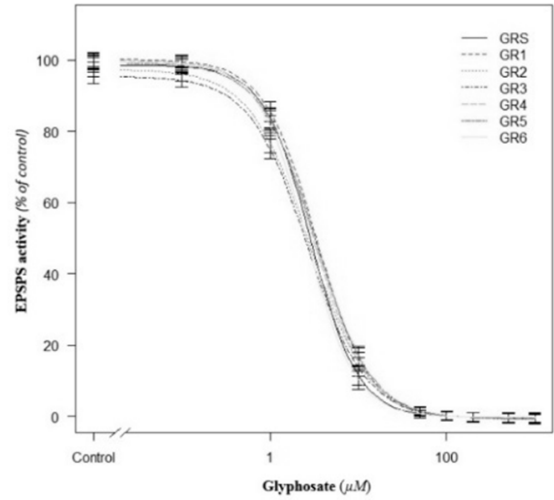

(a)

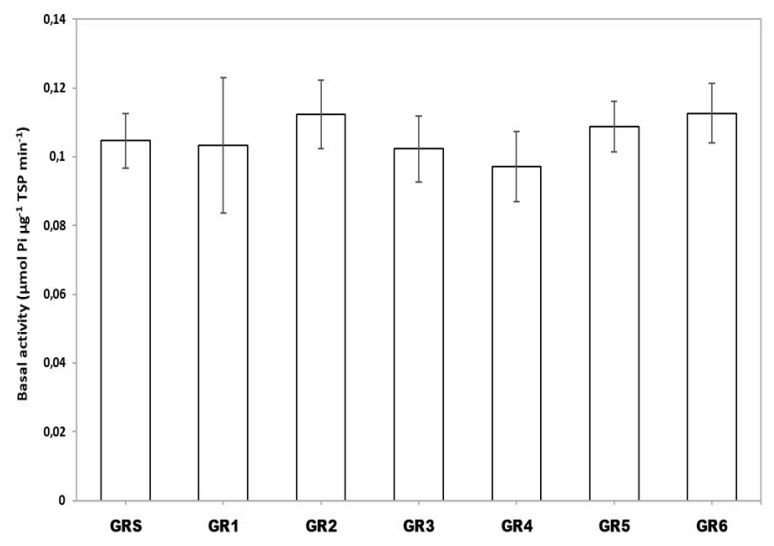

(b)

Figure 1. (a) 5-enolpyruvylshikimate-3-phosphate synthase (EPSPS) enzyme activity expressed as a percentage of the untreated control in leaf extracts of plants from resistant (GR) and susceptible (GS) populations of Johnsongrass. (b) Basal EPSPS activity, where histograms represent the treatment means (estimated in the absence of glyphosate) as vertical bars \pm standard error $(n=6)$. No significant differences between resistant $(\mathrm{R})$ and susceptible (S) populations were observed in both sets of data at $\alpha=0.05$.

\subsection{Glyphosate Metabolism Study}

The contribution of herbicide metabolism to non-target site resistance (NTSR) in glyphosate is somehow controversial. While some authors consider that this mechanism plays, at most, a minor role in glyphosate resistance [25,31], others claim this mechanism implies a decrease in the glyphosate concentration around its target site [32] or even changes in the translocation profile of glyphosate and its metabolites [16]. Glyphosate metabolism in plants is carried out by both a glyphosate oxidoreductase (GOX) putatively described as an aldo-keto reductase [17], which degrades the herbicide to glyoxylate and aminomethyl phosphonic acid (AMPA), and a carbon-phosphorus (C-P) lyase, which degrades glyphosate to sarcosine and inorganic phosphate, with formaldehyde present in that route as a reaction intermediate $[31,33,34]$. These two degradation pathways may be present or not in plants, although studies that include both degradation pathways are difficult and scarce $[15,16]$. Regardless of the metabolic pathway, glyphosate-tolerant legumes or weed species are characterized by a metabolic profile in which approximately $50 \%$ of the absorbed herbicide is degraded to other metabolites as fast as $96-144 \mathrm{~h}$ after treatment (HAT) [16,27] or even faster [17]. In our case, only AMPA and glyoxylate metabolites related to the GOX pathway were detected in both the resistant and susceptible Johnsongrass plants (Table 2).

This result does not mean there is a lack of C-P lyase activity, because this metabolic pathway is slower than the GOX one and sarcosine is usually detected only at very long incubation times [16,27]. In any case, the tissular glyphosate levels at 120 HAT were quite similar and high in all of the populations assayed, with the AMPA levels also not significantly different (Table 2). The fact that the glyoxylate levels in the susceptible population were lower than those observed in some of the resistant ones (GR1, GR2, GR4, and GR5) does not seem relevant, because the differences are too small compared to those observed in metabolism-based NTSR cases. Because non-metabolized glyphosate accounted for 89.6 (GR3) to $91.3 \%$ (GR5) of the total glyphosate and its metabolites, our data discard metabolism as the mechanism of resistance. 
Table 2. Metabolism of glyphosate at $120 \mathrm{~h}$ after treatment in glyphosate-resistant (GR1 to GR6) and -susceptible (GS) Johnsongrass populations. Plants were treated with $300 \mathrm{~g}$ ae ha ${ }^{-1}$ glyphosate at the 3-4 leaf stage.

\begin{tabular}{cccc}
\hline & \multicolumn{3}{c}{$\%$ Recovered Metabolites ${ }^{\mathbf{a}}$} \\
\hline Population & Glyphosate & AMPA & Glyoxylate \\
\hline GR1 & $89.7 \pm 3.9$ & $8.2 \pm 1.3 \mathrm{ab}$ & $2.1 \pm 0.8 \mathrm{a}$ \\
GR2 & $90.5 \pm 2.3$ & $7.5 \pm 2.6 \mathrm{ab}$ & $2.0 \pm 0.4 \mathrm{a}$ \\
GR3 & $89.6 \pm 4.2$ & $9.1 \pm 2.2 \mathrm{a}$ & $1.3 \pm 0.7 \mathrm{bc}$ \\
GR4 & $90.2 \pm 2.4$ & $8.0 \pm 0.9 \mathrm{ab}$ & $1.8 \pm 0.3 \mathrm{ab}$ \\
GR5 & $91.3 \pm 3.2$ & $6.4 \pm 2.1 \mathrm{~b}$ & $2.3 \pm 0.4 \mathrm{a}$ \\
GR6 & $90.0 \pm 3.9$ & $8.6 \pm 1.8 \mathrm{a}$ & $1.4 \pm 0.3 \mathrm{bc}$ \\
GS & $91.1 \pm 2.7$ & $7.9 \pm 0.9 \mathrm{ab}$ & $1.0 \pm 0.3 \mathrm{c}$ \\
$p$-value & 0.1239 & 0.0089 & 0.0001 \\
\hline
\end{tabular}

${ }^{a}$ Data are the means of six repetitions \pm S.E. Means with the same letters within a column are not significantly different at $\alpha=0.05$ based on Duncan's post hoc test. AMPA: aminomethyl phosphonic acid.

\subsection{Absorption and Translocation of ${ }^{14} \mathrm{C}$-Glyphosate}

Unlike other susceptible and resistant Johnsongrass populations studied, in which glyphosate leaf absorption becomes asymptotic at only 24 HAT [20,22], glyphosate absorption in Spanish glyphosate-resistant and -susceptible plants was slower and more gradual, with the penetration percentages ranging from approximately 20\% (24 HAT) to 80\% (96 HAT and following) and the radioactivity recovered accounting for more than $90 \%$ of the applied ${ }^{14} \mathrm{C}$-glyphosate (Table 3 ). In these terms, there were differences in leaf absorption between the $\mathrm{S}$ biotype and five of the six resistant biotypes studied, although these differences were only statistically significant 24 and 48 HAT. No differences among populations were found at both 72 and 120 HAT, while only GR5 plants absorbed more glyphosate than S ones at 96 HAT (Table 3). Therefore, when comparing the two most extreme cases, even though susceptible plants absorbed $75.1 \%$ more glyphosate than the GR5 biotype 24 HAT, these differences were downgraded to $63.6 \%$ at $48 \mathrm{HAT}$ and to non-significance with $22.8 \%$ and $11.8 \%$ 72 HAT and 120 HAT, respectively. Differences in glyphosate absorption as a source of herbicide resistance have been previously described in both glyphosate-resistant grass and broadleaved weeds, including one Argentinian glyphosate-resistant Johnsongrass biotype [20]. In our case, all the resistant biotypes had lower penetration values up to 72 HAT (Table 3), so a lower glyphosate leaf penetration as the mechanism of resistance would be plausible. However, we should consider these percentages carefully because differences in herbicide penetration do not always lead to resistance. In our case, although it is true that there were significant differences between the susceptible and resistant biotypes, it was also true that these differences faded over time, with all biotypes accumulating more than $74 \%$ of the recovered glyphosate 120 HAT. Whether the greater differences observed over shorter times of incubation or the subtle but significant differences observed at longer times made any difference in terms of glyphosate resistance is unknown because more than three-quarters of the glyphosate applied was present in all plants at the end of the experiment. Therefore, although it was very likely that glyphosate penetration played a role in the NTSR observed in our populations, the extent of this effect in the resistant response was not clear.

Likewise, there were clear differences in terms of glyphosate translocation between the susceptible and six resistant populations. The percentage of glyphosate remaining in the treated leaf 120 HAT ranged from $57.4 \%$ (GR2) to $70.4 \%$ (GR5) in resistant populations and decreased to $29.9 \%$ in the susceptible population (Table 4). This loss of herbicide in the susceptible treated leaves was found in both susceptible shoots and roots, with an accumulation of glyphosate that doubled, in most cases, that observed in resistant tissues (Table 4). 
Table 3. ${ }^{14} \mathrm{C}$ glyphosate uptake in resistant (GR1 to GR6) and susceptible (GS) Johnsongrass populations at different hours after treatment (HAT).

\begin{tabular}{cccccc}
\hline & \multicolumn{5}{c}{$\%$ of Applied Label } \\
\hline Population & $\mathbf{2 4}$ HAT & 48 HAT & 72 HAT & 96 HAT & 120 HAT \\
\hline GR1 & $18.3 \pm 1.5 \mathrm{a}$ & $39.8 \pm 3.0 \mathrm{a}$ & $72.4 \pm 4.5 \mathrm{a}$ & $80.1 \pm 6.9 \mathrm{ab}$ & $84.2 \pm 5.0 \mathrm{a}$ \\
GR2 & $20.8 \pm 4.0 \mathrm{a}$ & $40.3 \pm 3.2 \mathrm{a}$ & $70.3 \pm 6.1 \mathrm{a}$ & $80.4 \pm 4.1 \mathrm{ab}$ & $78.9 \pm 1.7 \mathrm{a}$ \\
GR3 & $17.4 \pm 2.8 \mathrm{a}$ & $42.6 \pm 4.9 \mathrm{a}$ & $71.8 \pm 5.5 \mathrm{a}$ & $78.9 \pm 5.9 \mathrm{ab}$ & $85.3 \pm 3.8 \mathrm{a}$ \\
GR4 & $22.7 \pm 2.5 \mathrm{ab}$ & $50.1 \pm 5.4 \mathrm{ab}$ & $70.3 \pm 4.2 \mathrm{a}$ & $81.6 \pm 4.1 \mathrm{ab}$ & $82.4 \pm 3.0 \mathrm{a}$ \\
GR5 & $17.3 \pm 1.7 \mathrm{a}$ & $36.8 \pm 3.8 \mathrm{a}$ & $62.6 \pm 3.1 \mathrm{a}$ & $70.3 \pm 3.1 \mathrm{a}$ & $74.8 \pm 4.1 \mathrm{a}$ \\
GR6 & $21.2 \pm 2.7 \mathrm{a}$ & $40.4 \pm 5.1 \mathrm{a}$ & $68.4 \pm 3.9 \mathrm{a}$ & $78.7 \pm 2.9 \mathrm{ab}$ & $82.6 \pm 4.8 \mathrm{a}$ \\
GS & $30.3 \pm 2.5 \mathrm{~b}$ & $60.2 \pm 6.7 \mathrm{~b}$ & $76.9 \pm 3.9 \mathrm{a}$ & $86.4 \pm 4.8 \mathrm{~b}$ & $83.6 \pm 5.3 \mathrm{a}$
\end{tabular}

a Data are the means of six repetitions \pm S.E. Means with the same letters within a column are not significantly different at $\alpha=0.05$ based on Duncan's post hoc test.

Table 4. ${ }^{14} \mathrm{C}$ glyphosate translocation in the resistant (GR1 to GR6) and susceptible (GS) Johnsongrass populations at $120 \mathrm{~h}$ after treatment.

\begin{tabular}{cccc}
\hline & \multicolumn{3}{c}{$\%$ of Absorbed Label a } \\
\hline Population & Treated Leaf & Shoot & Root \\
\hline GR1 & $60.8 \pm 4.2 \mathrm{c}$ & $24.6 \pm 4.1 \mathrm{~b}$ & $14.6 \pm 2.9 \mathrm{~d}$ \\
GR2 & $57.4 \pm 8.2 \mathrm{c}$ & $23.1 \pm 2.9 \mathrm{~b}$ & $19.5 \pm 4.1 \mathrm{~b}$ \\
GR3 & $62.8 \pm 6.3 \mathrm{bc}$ & $20.8 \pm 3.2 \mathrm{c}$ & $16.4 \pm 1.8 \mathrm{~cd}$ \\
GR4 & $70.1 \pm 2.9 \mathrm{a}$ & $15.8 \pm 3.2 \mathrm{~d}$ & $14.1 \pm 2.4 \mathrm{~d}$ \\
GR5 & $70.4 \pm 6.9 \mathrm{a}$ & $15.8 \pm 2.7 \mathrm{~d}$ & $13.8 \pm 4.5 \mathrm{~d}$ \\
GR6 & $67.9 \pm 4.7 \mathrm{ab}$ & $13.4 \pm 2.2 \mathrm{e}$ & $18.7 \pm 3.6 \mathrm{bc}$ \\
GS & $29.9 \pm 2.8 \mathrm{~d}$ & $34.1 \pm 2.1 \mathrm{a}$ & $36.0 \pm 3.9 \mathrm{a}$ \\
\hline
\end{tabular}

a Data are the means of six repetitions \pm S.E. Means with the same letters within a column are not significantly different at $\alpha=0.05$ based on Duncan's post hoc test.

Thus, reduced glyphosate translocation to non-treated shoots and roots was the primary mechanism of resistance in our six glyphosate-resistant Johnsongrass populations. Altered translocation has been described as the main source of glyphosate NTSR in many broadleaved and grass weed biotypes, including the two American glyphosate-resistant Johnsongrass cases [20,22]. This mechanism seems to be associated with the glyphosate accumulation in the vacuole that led to reduced translocation [10]. In these terms, the activation in resistant (R)plants of two genes (M10 and M11) encoding two ATP-binding cassette transporters has been described as a putative explanation for low glyphosate transport in glyphosate-NTSR Conyza Canadensis (revised in [25]). The development of similar mechanisms of glyphosate resistance in three distant Johnsongrass locations raises interesting questions. When TSR both fails to provide an adequate level of resistance and increases the fitness penalty [35,36], as in the case of glyphosate, NTSR genes tend to accumulate until the fitness penalties associated with them make individuals unviable [37]. This pattern seems to be the case for cross-pollinated grass weeds, such as rigid ryegrass (Lolium rigidum), in which more than one different mechanism of resistance has often been described [35]. However, Johnsongrass has usually been described as a rather homozygous species with a natural tendency for clonal rhizome dispersion and self-pollination [38]. Although the percentage of outcrossing in Johnsongrass is being revised [39], the high degree of asexual reproduction may imply lower levels of genetic diversity. These lower levels of diversity may explain the presence of only one NTSR mechanism in our populations, a mechanism shared by all the glyphosate-resistant Johnsongrass populations described to date. Whether Johnsongrass is a weed species prone to developing certain mechanisms of resistance over others when exposed to glyphosate-mediated selection pressure or not, is an issue that requires further investigation. 


\section{Materials and Methods}

\subsection{Plant Material}

A survey was conducted during June-July of 2015 and 2016 on Andalusian railways and roads starting from Cordoba city to other locations in the same region-Cordoba-Seville, Cordoba-Malaga, and Cordoba-Jaen. Next to these railways and roads are fruit and almond orchards, olive groves, and wheat and corn crop fields. Putative resistant (R) Johnsongrass seeds were collected from six different locations (GR1 to GR6 populations) and used for the assays described below. Seeds of a susceptible (S) Johnsongrass population were collected from a channel border that had not previously received glyphosate treatments near the laboratory facilities (Table S1).

All seeds were germinated in Petri dishes with filter paper moistened with distilled water and placed in a growth chamber at $28 / 18{ }^{\circ} \mathrm{C}$ (day/night) under a 16-h photoperiod, $850 \mu \mathrm{mol} \mathrm{m}^{-2} \mathrm{~s}^{-1}$ photosynthetic photon flux, and $80 \%$ relative humidity. Seedlings of the $\mathrm{R}$ and $\mathrm{S}$ populations were transplanted into pots containing sand and peat in a 1:1 $(v / v)$ ratio and placed in a growth chamber under the environmental conditions described above.

\subsection{Whole-Plant Dose-Response Assays}

Glyphosate treatments were applied at the 3-4-leaf growth stage. Herbicide was applied within a laboratory spray chamber (SBS-060 De Vries Manufacturing, Hollandale, MN, USA) equipped with 8002 flat fan nozzles delivering $200 \mathrm{~L} \mathrm{ha}^{-1}$ at $250 \mathrm{KPa}$ at a height of $50 \mathrm{~cm}$. The glyphosate (Roundup Energy $^{\circledR}$ SL, $450 \mathrm{~g} \mathrm{ae} \mathrm{L}^{-1}$, Monsanto Agricultura España, Madrid, Spain) rates ranged from 31.25 to $4000 \mathrm{~g}$ ae ha ${ }^{-1}$. After spraying, plants were maintained for 21 days in growth chambers under the previously described conditions. Afterward, R and S plants were cut at ground level, and growth was evaluated by plant mortality and aboveground fresh weight. The $\mathrm{LD}_{50}$ and $\mathrm{GR}_{50}$ rates were calculated for each experiment. The experiment was repeated twice and was arranged in a completely randomized design using five replicates (pots, four plants per pot) per rate.

\subsection{EPSPS Inhibition and Basal Activity Study}

EPSPS enzyme activity was studied according to Amaro-Blanco et al. [26]. Samples of $5 \mathrm{~g}$ of leaf tissue (three- to four-leaf growth stage) from each population were used for EPSPS extraction. The specific EPSPS activity in plants of each population was estimated in the presence and absence (basal activity) of glyphosate. EPSPS activity was determined using an EnzCheck Phosphate Assay Kit (Invitrogen, Carlsbad, CA, USA). The glyphosate concentrations used were 0, 0.1, 1, 10, 50, 100, 200, 500 , and $1000 \mu \mathrm{M}$. Three replicates at each glyphosate concentration were used, and the experiment was repeated twice. The release of phosphate on the bottom level was measured over $10 \mathrm{~min}$ at $360 \mathrm{~nm}$ in a spectrophotometer (DU-640, Beckman Coulter, Inc., Fullerton, CA, USA). EPSPS enzyme activity was expressed as the percentage of enzyme activity in the presence of glyphosate with respect to the control (without glyphosate).

\subsection{EPSPS Gene Sequencing}

Total RNA was isolated from leaves using TRIzol reagent (Invitrogen, Carlsbad, CA, USA) according to the manufacturer's instructions. RNA was then treated with TURBO DNase (RNase-Free; Ambion, Warrington, UK) to eliminate any DNA contamination and stored at $-80^{\circ} \mathrm{C}$. cDNA synthesis was carried out from $2 \mu \mathrm{g}$ of total RNA using the Moloney Murine Leukemia Virus (M-MLV) Reverse Transcriptase (Invitrogen, Carlsbad, CA, USA) in combination with oligo (dT)12-18 and random nonamers (Amersham Biosciences, Amersham, UK) according to the manufacturer's instructions. To amplify the EPSPS gene, primers previously designed by Perez-Jones et al. [30] (forward: 5' AGCTGTAGTCGTTGGCTGTG 3'; reverse: 5' GCCAAGAAATAGCTCGCACT 3') were used. These primers amplify a 543-bp fragment of the EPSPS gene that contains the mutation site that has been described to confer resistance to glyphosate in Lolium spp. [12,13]. Polymerase Chain Reaction (PCR) 
was carried out using cDNA from $50 \mathrm{ng}$ of total RNA, $1.5 \mathrm{mM} \mathrm{MgCl}_{2}, 0.2 \mathrm{mMdNTP}, 0.2 \mu \mathrm{M}$ of each primer, $1 \mathrm{x}$ buffer, and 0.625 units of a 100:1 enzyme mixture of non-proofreading (Thermusthermophilus) and proofreading (Pyrococcusfuriosus) polymerases (BIOTOOLS, Madrid, Spain) in a final volume of $25 \mu \mathrm{L}$. All PCR reactions were performed in duplicate, and the cycling conditions were $94{ }^{\circ} \mathrm{C}$, $3 \mathrm{~min}$; 35 cycles of $94{ }^{\circ} \mathrm{C}, 30 \mathrm{~s} ; 55^{\circ} \mathrm{C}, 30 \mathrm{~s}$; and $72{ }^{\circ} \mathrm{C}, 1 \mathrm{~min}$; and a final extension cycle of $72{ }^{\circ} \mathrm{C}$, $10 \mathrm{~min}$. An aliquot of the PCR product was loaded onto a 1\% agarose gel to check for correct band amplification. The rest of the PCR products were purified using ExoSAP-IT ${ }^{\circledR}$ for PCR Product Cleanup (USB, Ohio, OH, USA) as indicated by the manufacturers. Five purified PCR products per biotype were sequenced (STAB VIDA, Caparica, Portugal). Finally, the EPSPS DNA and the predicted peptide sequences were searched in the GenBank database using basic local alignment search tool (BLAST) on the website (http://www.ncbi.nlm.nih.gov/BLAST.cgi). The EPSPS sequences used for comparison were Argentinian glyphosate-resistant (HQ436352.1) and -susceptible (HQ436354.1) Johnsongrass accessions and glyphosate-resistant Lolium rigidum (ACB05442).

\subsection{Metabolism Study}

Johnsongrass plants at the 3- to 4-leaf stage were treated at a glyphosate rate of $300 \mathrm{~g}$ ae ha ${ }^{-1}$ as described in the dose-response assays section, and other plants were kept without treatment as non-treated controls. At $120 \mathrm{~h}$ after treatment, following the methodology described by Rojano-Delgado et al. [40], leaf tissues were washed with distilled water, flash-frozen in liquid nitrogen, and stored at $-40{ }^{\circ} \mathrm{C}$ until use. Glyphosate and its metabolites, i.e., AMPA, glyoxylate, sarcosine, and formaldehyde, were determined by reversed-polarity capillary electrophoresis using a 3D Capillary Electrophoresis Agilent G1600A instrument equipped with a diode array detector (wavelength range $190-600 \mathrm{~nm}$ ). The aqueous background electrolyte consisted of $10 \mathrm{mM}$ potassium phthalate, $0.5 \mathrm{mM}$ hexadecyltrimethylammonium bromide, and $10 \%$ acetonitrile at $\mathrm{pH} 7.5$. The calibration equations were established from non-treated plants and known concentrations of glyphosate and its metabolites. The experiment was performed in a completely randomized design with six repetitions per biotype.

\subsection{Absorption and Translocation of ${ }^{14} \mathrm{C}-$ Glyphosate}

To obtain the wetting agents and additives needed for absorption, ${ }^{14} \mathrm{C}$-glyphosate (American Radiolabeled Chemicals, Inc., Saint Louis, MO, USA) was added to the commercial herbicide to prepare a solution with a specific activity of $0.834 \mathrm{kBq} \mu \mathrm{L}^{-1}$. The final glyphosate concentration corresponded to $300 \mathrm{~g}_{\text {ae ha }}{ }^{-1}$ applied in $200 \mathrm{~L} \mathrm{ha}^{-1}$. One $1 \mu \mathrm{L}$ droplet was deposited by means of a micropipette (HTL LabMate) onto the adaxial surface of the second leaf of plants at the 3-leaf stage $(0.834 \mathrm{kBq} / \mathrm{plant})$. Preliminary assays with the populations studied here revealed that glyphosate absorption levelled off at $120 \mathrm{~h}$ after droplet application (results not shown). Three repetitions (considering every plant as a repetition) from each population were harvested at 24, 48, 72, 96, and 120 HAT. Treated leaves from each plant were carefully washed with $3 \mathrm{~mL}$ of a water-acetone $(1: 1 \mathrm{v} / \mathrm{v})$ solution to remove the unabsorbed ${ }^{14} \mathrm{C}$-glyphosate. The rinsate was analyzed by liquid scintillation spectrometry (LSS) on a Beckman LS 6500 scintillation counter. The remainder of the plant was carefully removed from the pot, and its roots were carefully washed with distilled water. Plants for penetration studies were kept undivided, while plants for translocation studies were divided into treated leaves, remaining shoot tissue, and roots. The plant parts obtained were dried at $60{ }^{\circ} \mathrm{C}$ for $96 \mathrm{~h}$ and combusted in a Packard Tri Carb 307 biological sample oxidizer. Evolved ${ }^{14} \mathrm{CO}_{2}$ was trapped and counted by LSS in an $18 \mathrm{~mL}$ mixture of Carbo-Sorb E and Permafluor E+ (1:1 v/v) (Perkin-Elmer, Packard Bioscience BV). Foliar absorption $(\%)$ was calculated as (radioactivity recovered from plant parts)/(total radioactivity recovered) $\times 100$. Translocation (\%) was calculated as (total radioactivity in treated leaf, shoot or root)/(total radioactivity in all tissues) $\times 100$. The amount of radiolabel deposited was determined by washing a treated leaf excised immediately after deposition (three replicates). The mean (SE) radioactivity recoveries ranged from $92 \%$ (6.3) to $94 \%$ (2.7) for resistant and susceptible Johnsongrass populations, respectively. 


\subsection{Statistical Analysis}

Dose-response and EPSPS enzyme activity data were subjected to non-linear regression analysis using a three-parameter log-logistic model (Equation (1)) to determine the glyphosate dose that resulted in a $50 \%$ reduction in growth $\left(\mathrm{GR}_{50}\right), 50 \%$ reduction in mortality $\left(\mathrm{LD}_{50}\right)$, or $50 \%$ inhibition of EPSPS activity $\left(\mathrm{I}_{50}\right)$.

$$
\mathrm{Y}=\mathrm{d} /\left[1+(\mathrm{x} / \mathrm{g})^{\mathrm{b}}\right]
$$

where $\mathrm{Y}$ is the reduction of aboveground fresh weight, survival, or enzyme activity, expressed as the percentage of that of the non-treated control; $d$ is the coefficient corresponding to the upper asymptote; $\mathrm{b}$ is the slope around the inflection point; $\mathrm{g}$ is the herbicide rate at the halfway inflection point $\left(\mathrm{GR}_{50}\right.$, $\mathrm{LD}_{50}, \mathrm{I}_{50}$ ); and $\mathrm{x}$ (independent variable) is the herbicide rate.

Regression analysis was conducted using the statistical freeware program R 3.2.4 with the drc package [41]. Resistance indexes (RI) were calculated as R-to-S $\mathrm{GR}_{50}, \mathrm{LD}_{50}$, or $\mathrm{I}_{50}$, values. The values of GR, LD, and I were considered significantly different when their respective RI ratios differed from 1 at $\alpha=0.05$. Data from shikimate, basal enzyme activity, metabolism, penetration, and translocation studies were subjected to analysis of variance (ANOVA), and the Tukey honestly significant difference test was used to separate population means when needed. For cases of replicated whole experiments, ANOVA was conducted according to a generalized randomized block design, with each run of the experiment representing a block. In neither case did the interaction terms include block significance, and thus, they were not included in the final ANOVA models. Model assumptions of a normal distribution of errors and homogeneity of variance were checked by visual inspection of the residual plots. When required, data were square-root transformed. In those few cases, the non-transformed values are presented for clarity.

Supplementary Materials: The following are available online at http://www.mdpi.com/2223-7747/9/3/313/s1: Figure S1: Partial sequences in the conservative region of 5-enolpyruvylshikimate-3-phosphate synthase (EPSPS) DNA isolated from both glyphosate-resistant (GR1 to GR6) and -susceptible (GRS) Johnsongrass populations; The EPSPS sequences used for comparison were glyphosate-resistant Sorghum halepense (HQ436352.1), susceptible Sorghum halepense (HQ436354.1), and glyphosate-resistant Lolium rigidum (ACB05442); Table S1: Herbicide records and locations of the different Johnsongrass populations.

Author Contributions: Conceptualization and supervision, R.D.P.; investigation (dose-response assays, shikimate tests), J.G.V.-G.; investigation (EPSPS assays and gene sequencing), C.P.-B.; investigation (metabolism studies), A.M.R.-D.; investigation (penetration/translocation studies) and writing-original draft preparation, J.M. All authors have read and agreed to the published version of the manuscript.

Funding: This research was funded by the Spanish Ministry of Economy and Competitiveness (AGL2016-78944-R) and the Asociación de Agroquímicos y Medioambiente.

Acknowledgments: We are grateful to Daniel Camacho-Calero for technical assistance in the completion of this research.

Conflicts of Interest: The authors declare no conflict of interest. The funders had no role in the design of the study; in the collection, analyses, or interpretation of data; in the writing of the manuscript, or in the decision to publish the results.

\section{References}

1. Holm, L.G.; Plucknett, D.L.; Pancho, J.V.; Herberger, J.P. The World's Worst Weeds: Distribution and Biology, 1st ed.; The University of Hawaii Press: Honolulu, HI, USA, 1977.

2. Vila-Aiub, M.M.; Balbi, M.C.; Gundel, P.E.; Ghersa, C.M.; Powles, S.B. Evolution of glyphosate-resistant Johnsongrass (Sorghum halepense) in glyphosate-resistant soybean. Weed Sci. 2007, 55, 566-571. [CrossRef]

3. Webster, T.M.; Nichols, R. Changes in the prevalence of weed species in the major agronomic crops of the southern United States: 1994/1995 to 2008/2009. Weed Sci. 2012, 60, 145-157. [CrossRef]

4. Steinrücken, H.C.; Amrhein, N. The herbicide glyphosate is a potent inhibitor of 5-enolpyruvyl-shikimic acid-3-phosphate synthase. Biochem. Biophys. Res. Commun. 1980, 94, 1207-1212. [CrossRef]

5. Duke, S.O.; Powles, S.B.; Sammons, R.D. Glyphosate-how it became a once in a hundred year herbicide and its future. OPMUB8 2018, 29, 247-251. [CrossRef] 
6. James, C. Global Status of Commercialized Biotech/GM Crops: 2010; International Service for the Acquisition of the Agri-Biotech Applications Briefs: Ithaca, NY, USA, 2010; Volume 42, pp. 1-15.

7. Powles, S.B. Evolved glyphosate-resistant weeds around the world: Lessons to be learnt. Pest Manag. Sci. 2008, 64, 360-365. [CrossRef]

8. Owen, M.D.K. World maize/soybean and herbicide resistance. In Herbicide Resistance and World Grains, 1st ed.; Powles, S.B., Shaner, D.L., Eds.; CRC Press: Boca Raton, FL, USA, 2001; pp. 101-163.

9. Ge, X.; André d'Avignon, D.; Ackerman, J.J.H.; Sammons, R.D. Rapid vacuolar sequestration: The horseweed glyphosate resistance mechanism. Pest Manag. Sci. 2010, 66, 345-348. [CrossRef]

10. Ge, X.; André d'Avignon, D.; Ackerman, J.J.H.; Sammons, R.D. In Vivo ${ }^{31}$ P-Nuclear Magnetic Resonance Studies of Glyphosate Uptake, Vacuolar Sequestration, and Tonoplast Pump Activity in Glyphosate-Resistant Horseweed. Plant Physiol. 2014, 166, 1255-1268. [CrossRef]

11. Powles, S.B.; Yu, Q. Evolution in action: Plants resistant to herbicides. Annu. Rev. Plant Biol. 2010, 61, 317-347. [CrossRef]

12. Fernández-Moreno, P.T.; Alcantara-de la Cruz, R.; Smeda, R.J.; De Prado, R. Differential Resistance Mechanisms to Glyphosate Result in Fitness Cost for Lolium perenne and L. multiflorum. Front. Plant Sci. 2017, 8, 1796. [CrossRef]

13. Fernández-Moreno, P.T.; Bastida, F.; De Prado, R. Evidence, mechanism and alternative chemical seedbank-level control of glyphosate resistance of a rigid ryegrass (Lolium rigidum) biotype from southern Spain. Front. Plant Sci. 2017, 8, 450. [CrossRef]

14. Gaines, T.A.; Zhang, W.; Wang, D.; Bukun, B.; Chisholm, S.T. Gene amplification confers glyphosate resistance in Amaranthus palmeri. Proc. Natl. Acad. Sci. USA 2010, 107, 1029-1034. [CrossRef] [PubMed]

15. De Carvalho, L.B.; Alves, P.L.D.C.A.; González-Torralva, F.; Cruz-Hipolito, H.E.; Rojano-Delgado, A.M. Pool of resistance mechanisms to glyphosate in Digitaria insularis. J. Agric. Food Chem. 2012, 60, 615-622. [CrossRef] [PubMed]

16. Rojano-Delgado, A.M.; Cruz-Hipolito, H.; De Prado, R.; Luque-de Castro, M.D.; Rodriguez-Franco, A. Limited uptake, translocation and enhanced metabolic degradation contribute to glyphosate tolerance in Mucuna pruriens var. utilis plants. Phytochemistry 2012, 73, 34-41. [CrossRef] [PubMed]

17. Pan, L.; Yu, Q.; Han, H.; Mao, L.; Nyporko, A.; Fan, L.; Bai, L.; Powles, S.B. Aldo-keto reductase metabolizes glyphosate and confers glyphosate resistance in Echinochloa colona. Plant Physiol. Preview 2019. [CrossRef] [PubMed]

18. González-Torralva, F.; Cruz-Hipolito, H.; Bastida, F.; Mülleder, N.; Smeda, R.J. Differential susceptibility to glyphosate among the Conyza weed species in Spain. J. Agric. Food Chem. 2010, 58, 4361-4366. [CrossRef]

19. Michitte, P.; De Prado, R.; Espinoza, N.; Ruiz-Santaella, J.P.; Gauvrit, C. Mechanisms of resistance to glyphosate in a ryegrass (Lolium multiflorum) biotype from Chile. Weed Sci. 2007, 55, 435-440. [CrossRef]

20. Vila-Aiub, M.M.; Balbi, M.C.; Distefano, A.J.; Fernandez, L.; Hopp, E.; Yu, Q.; Powles, S.B. Glyphosate resistance in perennial Sorghum halepense (Johnsongrass), endowed by reduced glyphosate translocation and leaf uptake. Pest Manag. Sci. 2011, 68, 430-436. [CrossRef]

21. Heap, I. The International Survey of Herbicide Resistant Weeds. Available online: http://www.weedscience. com (accessed on 29 January 2020).

22. Riar, D.S.; Norsworthy, J.K.; Johnson, D.B.; Scott, R.C.; Bagavathiannan, M. Glyphosate resistance in Johnsongrass (Sorghum halepense) biotype from Arkansas. Weed Sci. 2011, 59, 299-304. [CrossRef]

23. Bostamam, Y.; Malone, J.M.; Dolman, F.C.; Boutsalis, P.; Preston, C. Rigid ryegrass (Lolium rigidum) populations containing a target site mutation in EPSPS and reduced glyphosate translocation are more resistant to glyphosate. Weed Sci. 2012, 60, 474-479. [CrossRef]

24. Nandula, V.K.; Ray, J.D.; Ribeiro, D.N.; Pan, Z.; Reddy, K.N. Glyphosate resistance in tall waterhemp (Amaranthus tuberculatus) from Mississippi is due to both altered target-site and nontarget-site mechanisms. Weed Sci. 2013, 61, 374-383. [CrossRef]

25. Sammons, R.D.; Gaines, T.A. Glyphosate resistance: State of knowledge. Pest Manag. Sci. 2014, 70, 1367-1377. [CrossRef] [PubMed]

26. Amaro-Blanco, I.; Fernandez-Moreno, P.T.; Osuna-Ruiz, M.D.; Bastida, F.; De Prado, R. Mechanisms of glyphosate resistance and response to alternative herbicide-based management in populations of the three Conyza species introduced in southern Spain. Pest Manag. Sci. 2018, 74, 1925-1937. [CrossRef] [PubMed] 
27. Fernandez-Moreno, P.T.; Alcantara-de la Cruz, R.; Cruz-Hipolito, H.E.; Rojano-Delgado, A.M.; Travlos, I.; De Prado, R. Non-target site tolerance mechanisms describe tolerance to glyphosate in Avena sterilis. Front. Plant Sci. 2016, 7, 1220. [CrossRef] [PubMed]

28. Baerson, S.R.; Rodriguez, D.J.; Tran, M.; Feng, Y.; Biest, N.A.; Dill, G.M. Glyphosate-resistant goosegrass. Identification of a mutation in the target enzyme 5-enolpyruvylshikimate-3-phosphate synthase. Plant Physiol. 2002, 129, 1265-1275. [CrossRef]

29. Wakelin, A.M.; Preston, C. A target-site mutation is present in a glyphosate-resistant Lolium rigidum population. Weed Res. 2006, 46, 432-440. [CrossRef]

30. Perez-Jones, A.; Park, K.W.; Polge, N.; Colquhoun, J.; Mallory-Smith, C.A. Investigating the mechanisms of glyphosate resistance in Lolium multiflorum. Planta 2007, 226, 395-404. [CrossRef]

31. Duke, S.O. Glyphosate metabolism in plants. In Glyphosate Uso Sustentável, 1st ed.; Velini, E., Carbonari, C.A., Meschede, D.K., Bueno-Trindade, M.L., Eds.; PEPAF: Botucatu, Brazil, 2012; pp. 17-38.

32. Alcantara-de la Cruz, R.; Fernandez-Moreno, P.T.; Ozuna, C.V.; Rojano-Delgado, A.M.; Cruz-Hipolito, H.E.; Dominguez-Valenzuela, J.A.; Barro, F.; De Prado, R. Target and non-target site mechanisms developed by glyphosate-resistant hairy beggarticks (Bidens pilosa L.) populations from Mexico. Front. Plant. Sci. 2016, 7, 1492. [CrossRef]

33. Komoba, D.; Gennity, I.; Sanderman, H. Plant metabolism of herbicides with C-P bonds: Glyphosate. Pestic. Biochem. Physiol. 1992, 43, 85-94. [CrossRef]

34. Saroha, M.K.; Sridhar, P.; Malik, V. Glyphosate-tolerant crops: Genes and enzymes. J. Plant Biochem. Biotechnol. 1998, 7, 65-72. [CrossRef]

35. Preston, C.; Wakelin, A.M.; Dolman, F.C.; Bostaman, Y.; Boutsalis, P. A Decade of Glyphosate-Resistant Lolium around the World: Mechanisms, Genes, Fitness, and Agronomic Management. Weed Sci. 2009, 57, 435-441. [CrossRef]

36. Shaner, D.L.; Lindenmeyer, R.B.; Ostlie, M.H. What have the mechanisms of resistance to glyphosate taught us? Pest Manag. Sci. 2011, 68, 3-9. [CrossRef] [PubMed]

37. Menendez, J.; Rojano, M.A.; De Prado, R. Differences in Herbicide Uptake, Translocation, and Distribution as Sources of Herbicide Resistance in Weeds. In Retention, Uptake and Translocation of Agrochemical in Plants, 1st ed.; Myung, K., Satchivi, N.M., Kingston, C.K., Eds.; American Chemical Society: Washington, DC, USA, 2014; pp. 141-158.

38. Ohadi, S.; Hodnett, G.; Rooney, W.; Bagavathiannan, M. Gene flow and its consequences in Sorghum spp. CRC Crit. Rev. Plant Sci. 2017, 36, 367-385. [CrossRef]

39. Fernandez, L.; De Haro, L.A.; Distefano, A.J.; Martinez, M.C.; Lia, V.; Papa, J.C.; Olea, I.; Tosto, D.; Hopp, H.E. Population genetics structure of glyphosate-resistant Johnsongrass (Sorghum halepense L. Pers) does not support a single origin of the resistance. Ecol. Evol. 2013, 3, 3388-3400. [CrossRef] [PubMed]

40. Rojano-Delgado, A.M.; Ruiz-Jiménez, J.; De Castro, M.D.L.; De Prado, R. Determination of glyphosate and its metabolites in plant material by reversed-polarity CE with indirect absorptiometric detection. Electrophoresis 2010, 31, 1423-1430. [CrossRef]

41. Ritz, C.; Baty, F.; Streibig, J.C.; Gerhard, D. Dose-response analysis using R. PLoS ONE 2015, 10, e0146021. [CrossRef]

(C) 2020 by the authors. Licensee MDPI, Basel, Switzerland. This article is an open access article distributed under the terms and conditions of the Creative Commons Attribution (CC BY) license (http://creativecommons.org/licenses/by/4.0/). 